MARKETING AND BRANDING
RESEARCH $\begin{gathered}\text { INDUSTRIAL } \\ \text { MANAGEMENT } \\ \text { INSTITUTE }\end{gathered}$

\title{
An Investigation of the Effect of Relationship Marketing on Customer Gratitude and Consumer Behavior (Case Study: The Dealerships of Saipa Corporation in Ardabil Province)
}

\author{
Somayeh Saebnia ${ }^{1 *}$, Mohammad Feizi ${ }^{2}$, Mohammad Hasanzadeh ${ }^{3}$ \\ ${ }^{1}$ MA Student of Business Management, New Non-Profit Institution of Higher Education, Ardabil, Iran \\ ${ }^{2}$ Department of Management, Ardabil Branch, Islamic Azad University, Ardabil, Iran \\ ${ }^{3}$ Faculty of Humanities, University of Mohaghegh Ardabili, Ardabil, Iran
}

Keywords:

Relationship Marketing, Customer Gratitude,

Consumer Behavior, Dealerships of Saipa Corporation

Correspondence: saebniya@e.novinardebil .ac.ir

\section{Abstract}

The aim of dealerships to build a long-term relationship with customers is to make further profit. Today, relationship marketing is accompanied by understanding consumer behavior and meeting their need and according to the norm of mutual relationships, customer gratitude as customer buying behavior is the beginning of a motivation or an affective commitment to compensate seller's advantages. Therefore, this study attempts to consider the importance of customer in automobile industry and realize the effect of relationship marketing on customer gratitude and consumer behavior in dealerships of Saipa Corporation. The present study is applicable in terms of aim and correlational in terms of descriptive method. The statistical population includes all the customers of dealerships of Saipa Corporation in Ardabil Province. The sample size was calculated through Cochran's formula (384 customers) and to raise the confidence level, 400 people were selected randomly to answer the questionnaire. In order to analyze the descriptive findings, SPSS 20 Software was applied and to test the hypotheses, LISREL 8.8 Software was used. According to the results, the effect of relationship marketing on customer gratitude (path coefficient $=0.96$ ) and consumer behavior (path coefficient $=0.13$ ) is confirmed, which indicates the positive and significant effect on the measured variable in dealerships of Saipa Corporation in Ardabil Province.

(C)AIMI Journals

\section{Introduction}

Relationship marketing has been increasingly studied in marketing universities. Relationship marketing has been defined as guiding all marketing activities to creating, developing, and 
retaining successful relational exchanges (Morgan \& Hunt, 1994). Understanding the customer and their needs requires close relationship with them. Today, buyers face many questions when making decisions about the process of buying. Due to the variety of products, customers have many choices. Companies have found that attracting new customers costs 5 times more expensive than retaining the current customers and losing a customer is not only losing goods, but also losing the whole flow of purchases a customer has made during their lifetime. Researchers show that relationship marketing plays a considerable role in retaining the current customers and makes profit for the company which also can be considered as a competitive advantage. According to researches, today, companies are applying strategies that can retain the current customers and satisfy them simultaneously using related technologies and gaining information about customers. Moreover, long-lasting relationships can create loyalty (Venous \& Zohouri, 2011).

Relationship marketing leads to customer gratitude, for example, customer shows further respect for the company. In this sort of gratitude, the person expresses his/her gratitude to the legal or natural people verbally, nonverbally or both. Gratitude is a strong and cheap motivation and in marketing, according to the norm of mutual relationships, customer's gratitude as customer buying behavior is the beginning of a motivation or an affective commitment to compensate seller's advantages (Abbasi, 2015).

Retaining current customers through understanding consumer behavior and customer gratitude is considered as a basis for relationship marketing. If we consider all the customers entering the dealerships as the permanent customers and provide them with satisfactory services, they will be loyal to the company. Understanding consumer behavior plays a key role in retaining customers which is the main precondition to succeed and make profit for the dealerships. If the customer is satisfied with services, they will express gratitude and dealerships will be motivated to work on relationship marketing. Gratitude is an important factor that improves the quality of relationships and brings positive results for the seller. If customers are kept satisfied, they will not leave the organization, thus, some factors such as the availability of items, customer satisfaction, and the quality of services must be monitored, since customers are sensitive to relationships. Studies on previous experiences, expectations, and tendencies indicate customer's future behavior. In this case, relationship marketing collects information that helps the company to identify and retain more loyal customers (Abbasi, 2015). In fact, relationship marketing is a strategy to overcome customer loss through consumer behavior, which attracts customers' satisfaction and trust, creates customer gratitude, and increases company's profitability. Due to the nature of Saipa's dealerships, they attempt to retain customers, since their survival depends on customers. Following this, if they retain their current customers, they will be more successful. Relationship marketing is a new approach in automobile industry and aims at creating close and long-term relationships to understand customers and satisfy them (Ndubisi \& Wah, 2005). Therefore, the present research attempts to study the effect of relationship marketing (one of the common issues of marketing which is applied to customer retention) on customer gratitude and consumer behavior among the customers of the dealerships of Saipa Corporation in Ardabil Province. Moreover, the objectives of this research are studying the effect of relationship marketing on 
customer gratitude in Saipa's dealerships of Ardabil Province and studying the effect of relationship marketing on consumer behavior in Saipa's dealerships of Ardabil Province.

\section{The Literature Review}

Relationship marketing is one of the widest concept that can be concluded from all marketing viewpoints concentrating on relationship (Bonnemaizon, Cova, \& Louyot, 2007). This term was officially introduced by Leonardo Beri in 1983 (Sin et al., 2005), who defined it as attracting, retaining, and increasing relationship with customer. From Kotler's viewpoint, relationship marketing includes creating, retaining, and managing strong relationships with customers and other beneficiaries (Kotler \& Armstrong, 1999). Consumer behavior is a new topic in marketing, since the first books published in this regard return to 1968. Most universities have no researches on this topic before 1970, however, it has gained importance recently. In 1970, a special group was established to research on consumer behavior and in 1990, this group included 1500 members and 30 countries. Customer gratitude is optional and is considered as an emotional reaction, which indicates that a profit is received from the seller. Customer gratitude is less important in research; however, it is one of the most important ways to build relationship between managers, employees, and customers. Gratitude is optional and will simulate the norm of mutual action if the customer understands the received advantages. This understanding can improve the relationships and lead to long-term success in marketing (Fazal e Hasan, Lings, Neale, \& Mortimer, 2014). Customers pay money to the seller based on gratitude and tendency applying mutual behavior. The great amount of tendency received by customers will lead to great amount of gratitude (Huang, 2015).

Abbasi (2015) conducted a study to find that how much relationship marketing affects customer gratitude. Using the mediating role, the dimensions of relationship marketing in the fields of direct electronic post, tangible reward, tangible benefits, and consumer perceptions were studied. According to the results, relationship marketing and its four dimensions have a significant effect on customer gratitude.

Ranjbarian and Barari (2008) studied the effect of relationship marketing foundations including commitment, trust, communications, and conflict management on customer loyalty. This research was a survey-descriptive study using 312 customers of a private and a public bank in Isfahan through questionnaire. The results indicated that in the public bank, four factors showed a positive effect on loyalty and in the private one, all variables except communications showed a positive effect.

In another research conducted by Sobhani Fard and Cheraghali (2014) in Saipa Corporation, it was indicated that in this company, customers' service quality can be measured by nine indices. Moreover, the quality of services perceived by customers has a positive effect on their satisfaction of the company and it was found that the indices of service quality have a direct relationship with one another.

Another research results conducted by Jalali Gorgan and Mehrani (2012) indicated that there was a significant relationship between all the applied methods and customer's tendency to purchase. Moreover, the significant relationship between customer's tendency to purchase and relationship satisfaction as well as relationship commitment was confirmed. The significant relationships between relationship satisfaction and trust, trust and relationship 
commitment, and relationship commitment and customer's purchase behavior were confirmed as well.

In another research conducted by Fotea, Fotea, and Poli (2011) in Romania, researchers attempted to find a long-term relationship between Romanian companies and customers using the effect of relationship marketing on customers' satisfaction. According to the results, the Romanian companies can improve their relationship with customers through marketing researches and by measuring them and increase their sale by attracting their customers' satisfaction.

Lo (2012) in a study under the title of "A study of relationship marketing on customer satisfaction" in tourism industry, hospitals, schools, and firms of Taiwan concluded that trust and satisfaction as important indices to show a better image of industry are of great importance.

The result of a research conducted by Huang (2015) indicated that investment alternatives in relationship marketing such as direct electronic post, tangible reward, interpersonal communications, and gradual treatment show different effects on customer gratitude as well as loyalty. Moreover, according to the results, in gradual time, the most effective relationship marketing tactics in order to enhance customer gratitude are interpersonal communications and tangible rewards.

\section{The Study}

The conceptual model of the present study is presented in Figure 1.

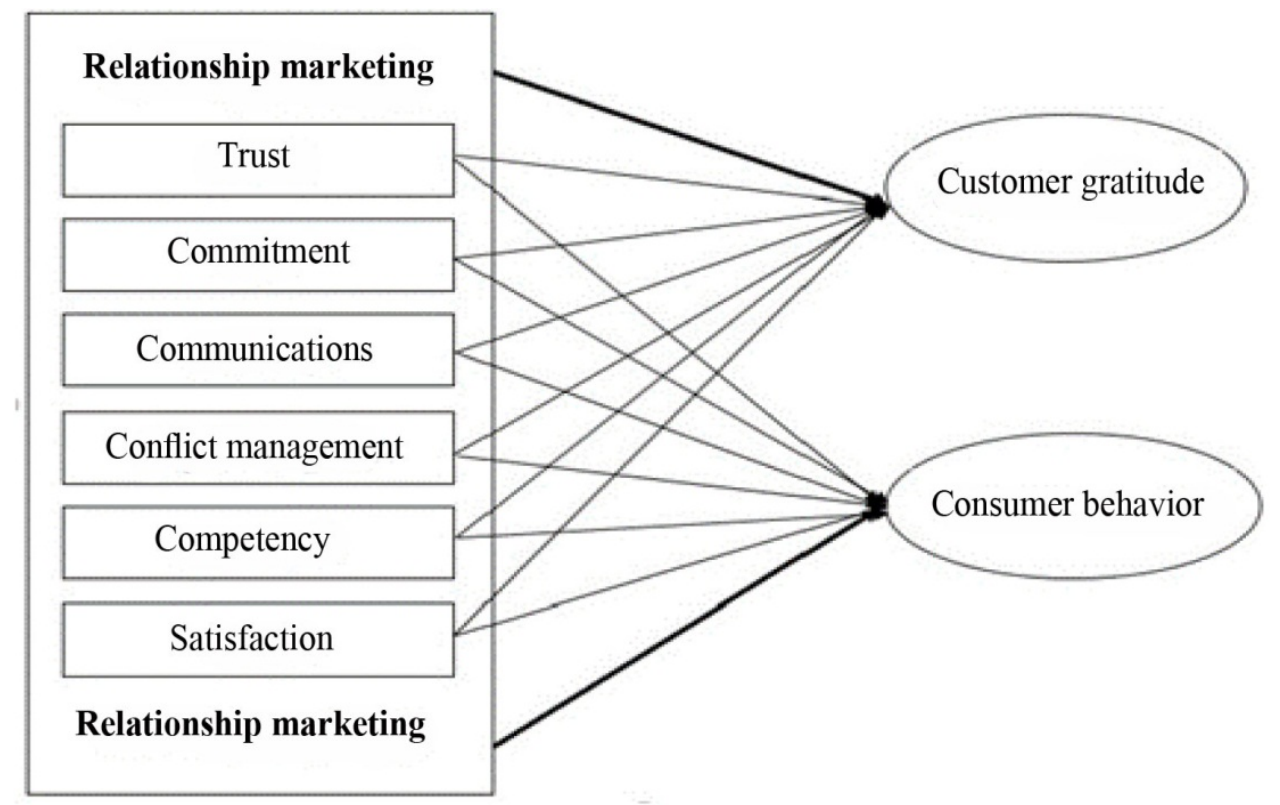

Figure 1. The conceptual model of the research

As shown in Figure 1, this research attempts to study the effect of relationship marketing and its six components, namely trust, commitment, communications, conflict management, competency, and customer satisfaction on customer gratitude and consumer behavior. 


\section{Research Hypotheses}

The following research hypotheses guided the study:

$\mathbf{H}_{\mathbf{1}}$ : Relationship marketing has a significant effect on customer gratitude.

$\mathbf{H}_{2}$ : Relationship marketing has a significant effect on consumer behavior.

\section{Method}

The present study is applicable in terms of aim and descriptive-correlational in terms of data collection. Moreover, the current study is also totally based on structural equations modeling. This sort of modeling is the expansion of linear model enabling the researcher to test a group of regression equations simultaneously (Arshadi, 2007).

In this research, the statistical population includes all the customers of Saipa dealerships in Ardabil Province. The information was collected from February 8th to March 19th in 2017.

Simple random sampling was applied to this research. In order to access to statistical samples two methods were used: In the first method, a channel was created on Telegram under the title of "the questionnaire for master's thesis" and customers, who had referred to Saipa dealerships in Ardabil province in the determined period, were asked to answer the questionnaire. In the second method, one customer was selected randomly among every three customers who had referred to dealerships in the determined period from 8:30 A.M. to 1:00 P.M. to fulfill the questionnaire.

Due to the high number of customers and lack of an integrated system to show the customers by province, Cochran's Formula was applied to this research. The sample size of this study includes 384 customers, however, to enhance the confidence level, 400 customers were considered as sample size.

Moreover, to study the literature and background, library method and Internet search were applied and to collect the data, field method and questionnaire were used. Relationship marketing was measured through six-dimension questionnaire (trust, commitment, communications, conflict management, competency, and customer satisfaction) including 32 questions of five-point Likert Scale (from entirely disagree to entirely agree). The questionnaire of consumer behavior included 14 questions of five-point Likert Scale (from too little to too much). The variable of customer gratitude was measured using the questionnaire designed by Mccullough, Emmons, and Tsang (2002). This six-item questionnaire is designed in the form of five-point Likert Scale (from "is not true about me at all" to "is totally true about me").

\section{Results}

In order to measure the reliability of questions in the questionnaire, an initial sample including 30 questionnaires was pretested; then using the collected data, confidence coefficient was calculated through Cronbach's Alpha. The results of reliability questionnaires are indicated in Table 1. 
Table 1

The Reliability of Questionnaires

\begin{tabular}{|c|c|c|c|c|}
\hline \multirow{2}{*}{ Questionnaire } & \multirow{2}{*}{ The Dimensions } & \multirow{2}{*}{ The Number of Questions } & \multicolumn{2}{|c|}{ Cronbach's Alpha Coefficient } \\
\hline & & & In Detail & In Total \\
\hline \multirow{6}{*}{ Relationship Marketing } & Trust & 5 & 0.683 & 0.941 \\
\hline & Commitment & 5 & 0.714 & \\
\hline & Communications & 5 & 0.810 & \\
\hline & Conflict Management & 5 & 0.807 & \\
\hline & Competency & 5 & 0.809 & \\
\hline & Customer Satisfaction & 7 & 0.853 & \\
\hline Gratitude & - & 6 & - & 0.818 \\
\hline Consumer Behavior & - & 14 & - & -.841 \\
\hline
\end{tabular}

According to Table 1, the values of Cronbach's Alpha for all three questionnaires were higher than 0.7 , which indicates that these questionnaires are highly reliable. To measure the validity of the questionnaires, first and second order factor analyses were applied using LISREL 8.8 Software. According to Figures 2 and 3, both measuring models are significant in terms of factor loading and being out of absolute value (1.96).

Considering the standard estimate model of relationship marketing presented in Figure 2, second order factor model is defined as a sort of factor models. In this model, latent factors measured by visible variables are influenced by a more infrastructural variable at a higher level. In other words, according to Esfidani and Mohsenin (2013), second order factor models are studied when first order factors are determined by higher-rate factor structure.

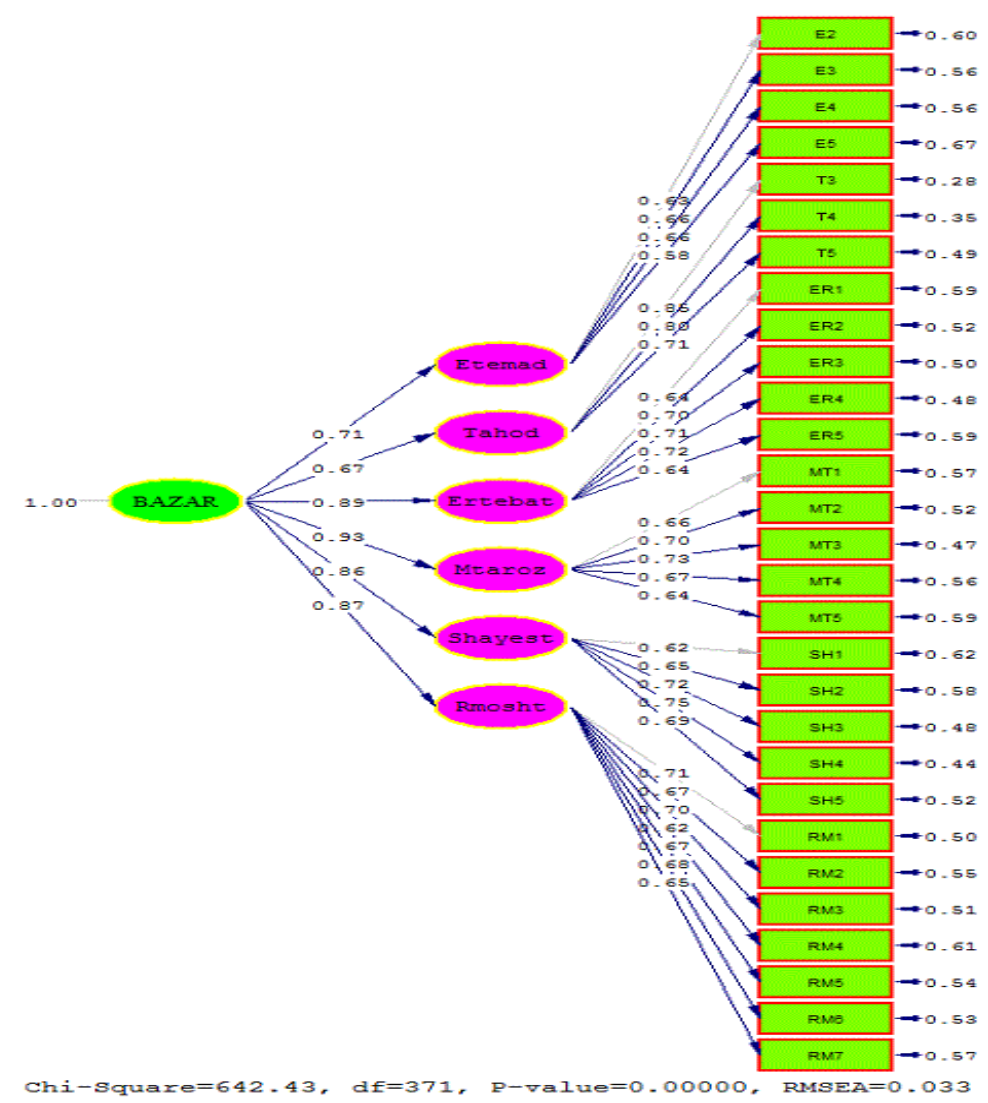

Figure 2. The standard estimate model of relationship marketing 
Figure 3 shows the significant number model ( $\mathrm{t}$ static) of relationship marketing.

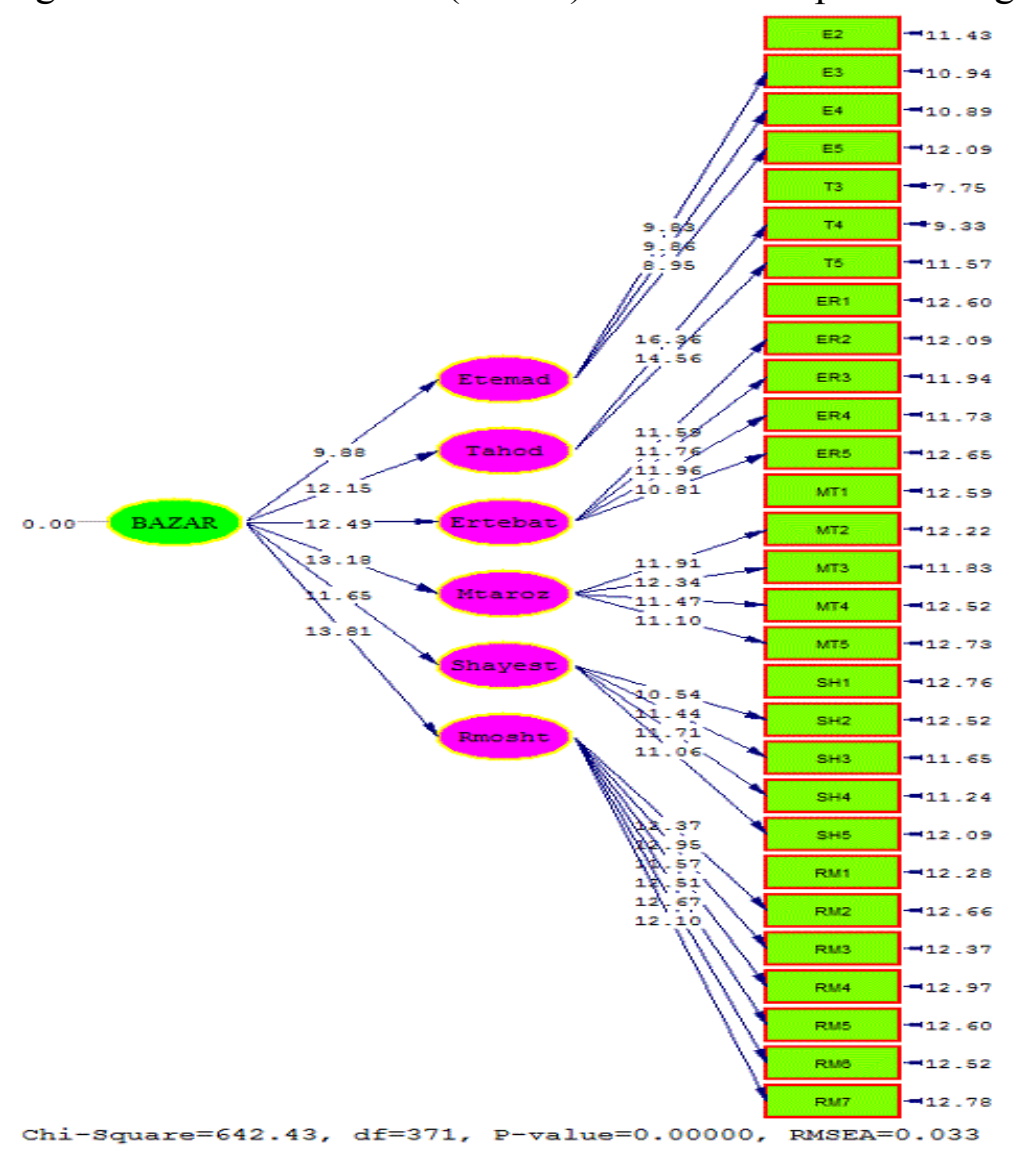

Figure 3. The significant number model ( $\mathrm{t}$ static) of relationship marketing

\section{Research Descriptive Findings}

In descriptive statistics, the collected data has been studied in terms of gender, education, age, and number of times customers have referred to dealerships. The results are illustrated in Table 2.

Table 2

The Results of Descriptive Statistics

\begin{tabular}{|c|c|c|c|c|}
\hline \multicolumn{3}{|c|}{ Index } & \multicolumn{2}{|c|}{ Frequency } \\
\hline \multirow[t]{2}{*}{ Gender } & \multicolumn{2}{|c|}{ Female } & \multicolumn{2}{|c|}{ Male } \\
\hline & \multicolumn{2}{|c|}{$19.7 \%$} & \multicolumn{2}{|c|}{$80.3 \%$} \\
\hline \multirow[t]{2}{*}{ Education } & Diploma and Lower & Associate Degree & $\mathrm{BA}$ & $\mathrm{MA}$ and $\mathrm{PhD}$ \\
\hline & $34 \%$ & $19 \%$ & $24.3 \%$ & $22.8 \%$ \\
\hline \multirow[t]{2}{*}{ Age } & Under 30 & Between 30 and 40 & Between 40 and 50 & older than 50 \\
\hline & $29.3 \%$ & $31.3 \%$ & $30 \%$ & $9.5 \%$ \\
\hline \multirow{2}{*}{$\begin{array}{c}\text { Number of Times Customers } \\
\text { have Referred }\end{array}$} & Less than 5 Times & Between 5 to 10 Times & Between 10 to 15 Times & More than 15 Times \\
\hline & $21.3 \%$ & $38.8 \%$ & $25 \%$ & $15 \%$ \\
\hline
\end{tabular}

\section{The Structural Model of Path Analysis}

The measuring model in this research includes 6 latent variables, namely trust, commitment, communications, conflict management, competency, and customer satisfaction. The indices and values of fit model are as following: $\chi^{2} / \mathrm{df}=2.842$, the goodness of fit index $(\mathrm{GFI})=0.87$, the root mean square error of approximation (RMSEA) $=0.047$, the comparative fit index 
$(\mathrm{CFI})=0.97$, the normed fit index $(\mathrm{NFI})=0.95$, the non-normed fit index $(\mathrm{NNFI})=0.90$, the incremental fit index (IFI) $=0.91$, and the adjusted goodness of fit index (AGFI) $=0.90$. Generally, when working with LISREL Software, each index may not be the reason of fit model by itself. In fact, these indices must be interpreted together. According to the above numbers, this model is good-fitted.

Figure 4 exhibits the standard estimate model based on the pair correlational coefficients of conceptual model.

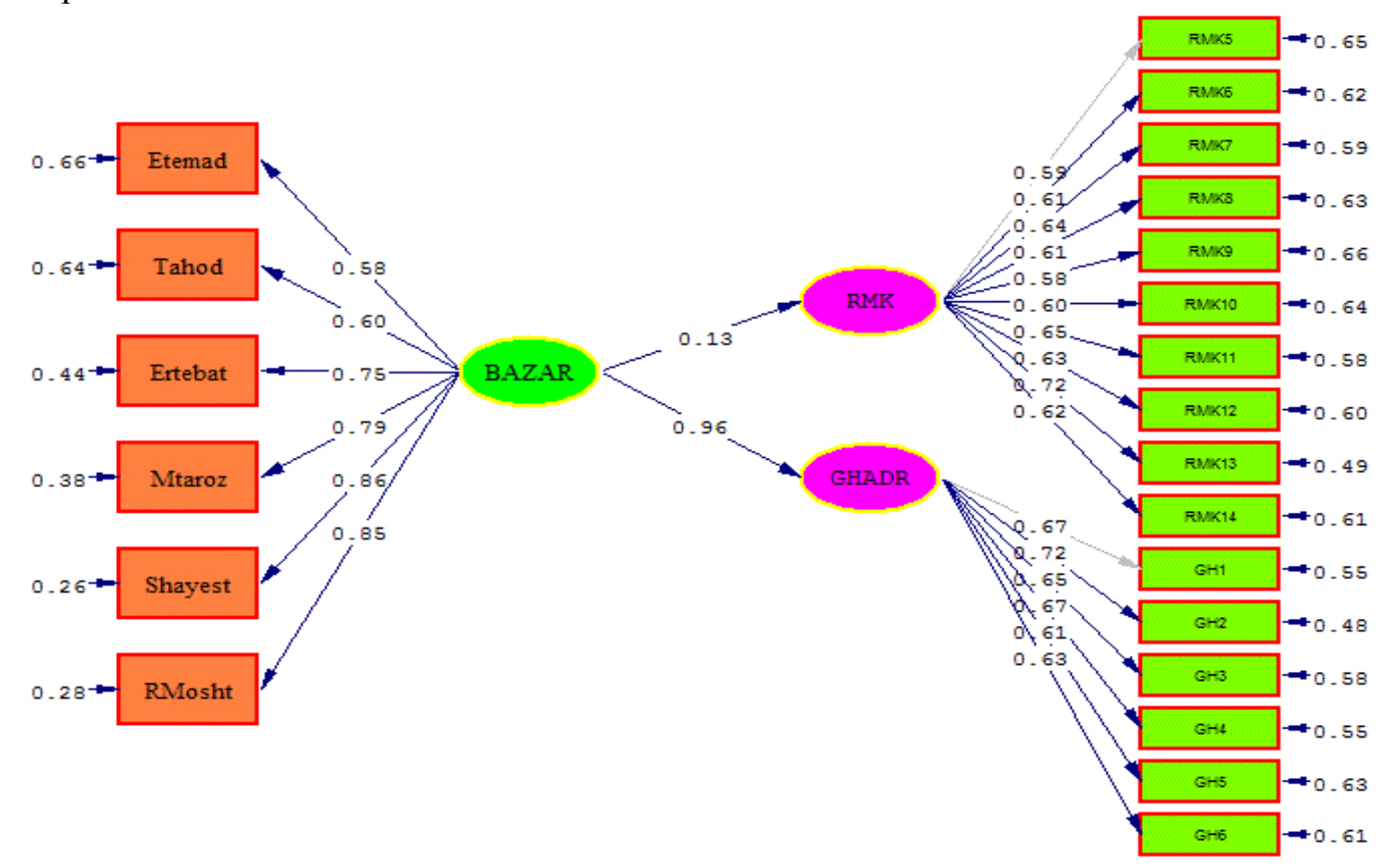

Chi-Square=588.32, df=207, P-value=0.00000, RMSEA=0.047

Figure 4. The standard estimate model based on the pair correlational coefficients of conceptual model

Figure 4 indicates the structural equations model at the standard coefficient estimate form. Among the studied variables, the most effective and significant variables were customer gratitude (0.96) and consumer behavior (0.13), respectively. Figure 5 shows the structural equations model at the significant number form. The significant number model is presented to find that whether the relationship between the structure and index is significant or not. The significant number model or t-value indicates the significance of each parameters and if its value is higher than 1.96 (absolute value), the parameters are significant. Since some significant numbers of the parameters are higher than 1.96, the hypotheses are confirmed (Esfidani \& Mohsenin, 2013). Table 5 shows the significant number model of the conceptual model. 


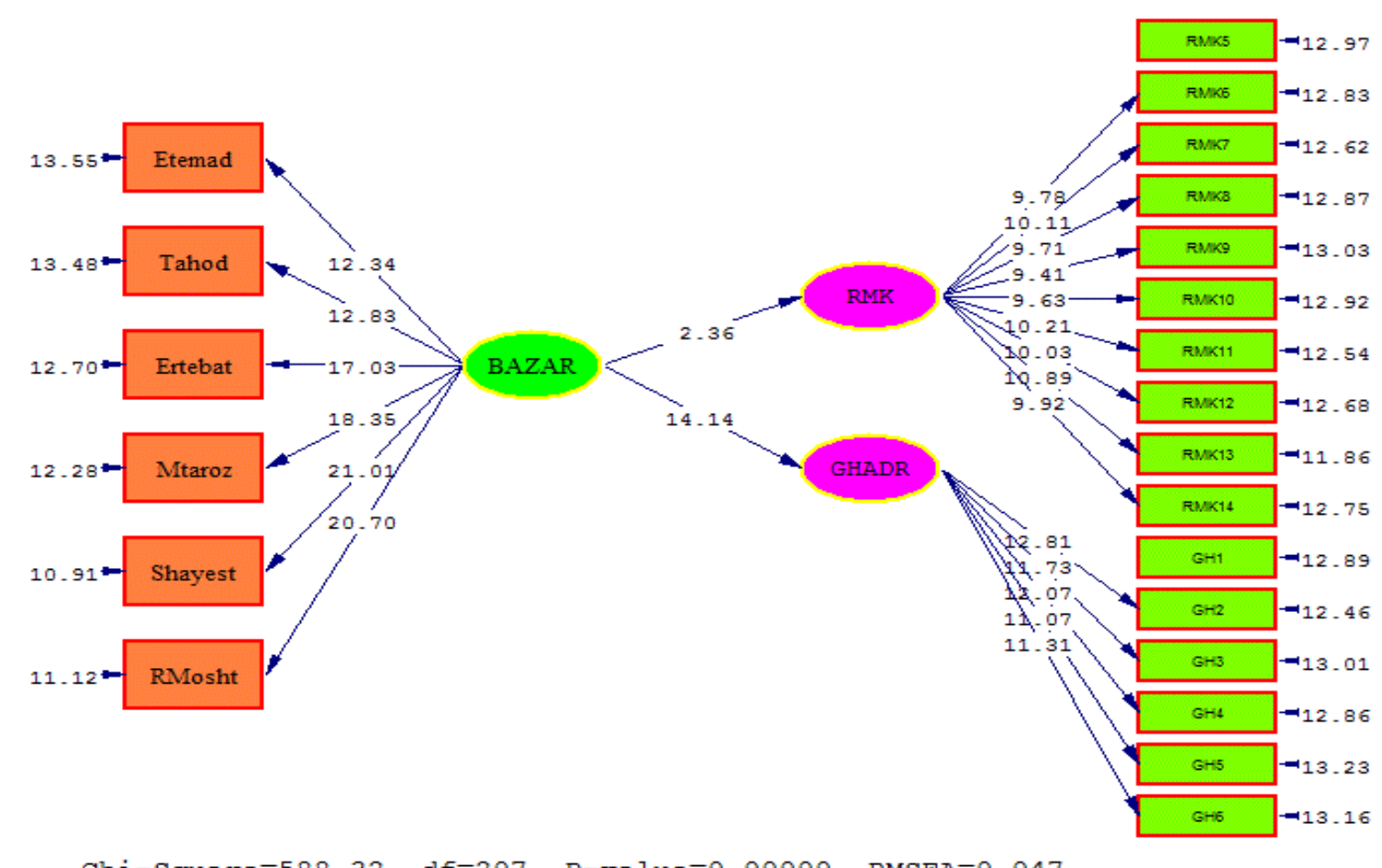

Chi-Square $=588.32, \mathrm{df}=207, \mathrm{P}-\mathrm{value}=0.00000, \mathrm{RMSEA}=0.047$

Figure 5. The significant number model of the conceptual model

Generally, the results of hypotheses tests and statistics are illustrated in Table 3.

Table 3

The Results of Hypotheses Test

\begin{tabular}{lcccc}
\hline Hypotheses & Path Coefficient & t-Value & Significance Level & Result \\
\hline Relationship Marketing $\rightarrow$ Consumer Behavior & 0.13 & 2.36 & $<0.05$ & Confirmed \\
Relationship Marketing $\rightarrow$ Customer Gratitude & 0.96 & 14.14 & $<0.05$ & Confirmed \\
Trust $\rightarrow$ Consumer Behavior & 0.43 & 5.00 & $<0.05$ & Confirmed \\
Commitment $\rightarrow$ Consumer Behavior & 0.45 & 4.54 & $<0.05$ & Confirmed \\
Communications $\rightarrow$ Consumer Behavior & 0.28 & 3.19 & $<0.05$ & Confirmed \\
Conflict Management $\rightarrow$ Consumer Behavior & 0.03 & 0.32 & $<0.05$ & Rejected \\
Competency $\rightarrow$ Consumer Behavior & 0.33 & 3.44 & $<0.05$ & Confirmed \\
Customer Satisfaction $\rightarrow$ Consumer Behavior & 0.10 & 1.99 & $<0.05$ & Confirmed \\
Trust $\rightarrow$ Customer Gratitude & 0.46 & 10.43 & $<0.05$ & Confirmed \\
Commitment $\rightarrow$ Customer Gratitude & 0.48 & 11.00 & $<0.05$ & Confirmed \\
Communications $\rightarrow$ Customer Gratitude & 0.56 & 13.66 & $<0.05$ & Confirmed \\
Conflict Management $\rightarrow$ Customer Gratitude & 0.62 & 15.92 & $<0.05$ & Confirmed \\
Competency $\rightarrow$ Customer Gratitude & 0.78 & 25.37 & $<0.05$ & Confirmed \\
Customer Satisfaction $\rightarrow$ Customer Gratitude & 0.78 & 25.57 & $<0.05$ & Confirmed \\
\hline
\end{tabular}

According to Table 3, except sixth hypothesis $(\mathrm{P}<0.05, \mathrm{t}=0.32)$ all other hypotheses are confirmed.

\section{Discussion and Conclusion}

Marketing and relationship marketing have gained importance simultaneously in studies related to dealerships. Saipa dealership works under the supervision of Saipa Automobile Corporation. These dealerships aim at providing after-sale services to gain profit and sell the 
products of this corporation. The present study investigated the effect of relationship marketing on customer gratitude and consumer behavior among the customers of Saipa dealerships in Ardabil Province. After reviewing the domestic and foreign researches as well as different viewpoints about marketing relationship, consumer behavior, and customer gratitude, the theoretical framework was selected. In order to confirm the hypotheses, the required data was collected through questionnaires among 400 customers of Saipa dealerships in Ardabil Province. This data was analyzed using statistical techniques. According to the results, relationship marketing and its dimensions have a significant effect on customer gratitude. Moreover, relationship marketing and its dimensions except conflict management have a significant effect on consumer behavior.

In future researches, it is recommended that researchers investigate the effect of relationship marketing on gratitude and consumer behavior considering other mediating variables such as social factors or services quality. The present study is restricted to a particular part of Iran and Ardabil Province cannot be a complete representation of customers' behavior. Therefore, it is recommended that all the dealerships of Saipa Corporation be considered as the statistical population through cluster sampling. It is also recommended that employees be trained to make a good relationship with customers. In this research, data was collected through questionnaire, however, detailed information can be gathered using interview.

\section{References}

Abbasi, M. (2015). An investigation of the effect of relationship marketing on customer gratitude (Case study: The branches of Dana Insurance in Tehran) (Unpublished master's thesis). Faculty of Management and Accounting, Islamic Azad University, Central Tehran Branch, Tehran, Iran.

Arshadi, N. (2007). Designing and testing a model of important antecedents and outcomes of job motivation in the employees of National Iranian South Oil Company (Unpublished doctoral dissertation). Shahid Chamran University of Ahwaz, Ahwaz, Iran.

Bonnemaizon, A., Cova, B., \& Louyot, M. C. (2007). Relationship marketing in 2015: A delphi approach. European Management Journal, 25(1), 50-59.

Esfidani, M., \& Mohsenin, S. (2013). Structural equations modeling using LISREL Software. Tehran, Iran: Mehrban Publications.

Fazal e Hasan, S., Lings, I. N., Neale, L, \& Mortimer, G. (2014). The role of customer gratitude in making relationship marketing investments successful. Journal of Retailing \& Consumer Services, 21(5), 788-796.

Fotea, I., Fotea, S., \& Poli, E. (2011). Applying relationship marketing principles based on customer satisfaction research in a direct marketing company in Romania. International Journal of Business \& Management Studies, 3(2), 109-119.

Huang, M. H. (2015). The influence of relationship marketing investments on customer gratitude in retailing. Journal of Business Research, 68(6), 1318-1323.

Jalali Gorgan, M., \& Mehrani, H. (2012). Studying the relationship of relationship marketing methods and purchase behavior in retail chain stores of Gorgan. Journal of Industrial Strategic Management, 10(30), 57-72.

Kotler, P. T., \& Armstrong, G. (1999). Principles of marketing. New-Jersey: Prentice-Hall.

Lo, S. C. (2012). A study of relationship marketing on customer satisfaction. Journal of Social Sciences, 8(1), 91-94.

Mccullough, M. E., Emmons, R. A., \& Tsang, J. A. (2002). The grateful disposition: A conceptual and empirical topography. Journal of Personality \& Social Psychology, 82(1), 112-127.

Morgan, R. M., \& Hunt, S. D. (1994). The commitment-trust theory of relationship marketing. Journal of Marketing, 58(3), $20-38$.

Ndubisi, N. O., \& Wah, C. K. (2005). Factorial and discriminant analyses of the underpinnings of relationship marketing and customer satisfaction. International Journal of Bank Marketing, 23(7), 542-557. 
Ranjbarian, B., \& Barari, M. (2008). The effect of relationship marketing foundations on customer loyalty: Comparing private and public banks. Quarterly Journal of Business Management, 1(2), 83-100.

Sin, L. Y. M., Tse, A. C. B., Yau, O. H. M., Chow, R. P. M., Lee, J. S. Y., \& Lau, L. B. Y. (2005). Relationship marketing orientation: Scale development and cross-cultural validation. Journal of Business Research, 58(2), 185-194.

SobhaniFard, Y., \& Cheraghali, S. (2014). An investigation of the quality of sale services and their effect on customer satisfaction. Journal of Management and Development Process, 27(3), 131-146.

Venous, D., \& Zohouri, B. (2011). Analyzing the effect of value dimensions of relationship marketing and brand loyalty of mobile phones. Quarterly Journal of Business Management, 3(8), 149-172. 